INTRODUCTION

\title{
The Law of the Seabed
}

\author{
Catherine Banet
}

\section{Focus of the Book}

Humankind has always been fascinated by the seabeds for their mysteries, their perils and their riches, along with the beauty of their biological diversity. Moreover, the ocean floor comprises a constellation of components that are, at the same time, fragile and vital to sustainability and the balance of the rest of the world's interdependent eco-systems.

For an area which is barely accessible to most human beings, the ocean floor plays a major role in the Earth ecological balance. Oceans cover 70 percent of the Earth surface and constitute more than 95 percent of the planet living space. The deep seabed beyond national jurisdiction covers half of the Earth's surface, and $5^{0}$ per cent of is below 3,000 meter depth. The seabeds sustain important functions and ecosystem services, including nutrient regeneration, carbon sequestration, biological and mineral resources.

Both the exploitation and the conservation of seabeds pose fundamental questions for consideration by jurists, policy makers and negotiators, issues associated with the man-made rule of law but with consequences surpassing purely legal considerations and that require great qualities of judgement and care. Short-term commercial aspirations compete with national strategic and technological goals as well as global ecological concerns. There is, as often in the case, a balance to strike between enabling seabed resources use and preserving fragile environments. The question for lawyers is how to best ensure that known and potential impacts are taken into account when taking decisions as to the use of the seabed and its resources, and how to ensure that access to seabed resources benefit all stakeholders in an equitable and sustainable manner. Legal principles such as the precautionary principle or common heritage of mankind must serve as guidance. Procedural tools, such as environmental impact assessments (EIAs), aim to make sure that consequences are assessed and interested parties heard. Marine management tools aim to ensure long-term coherence between activities and interests. This book aims to offer a new perspective on the juridical aspects raised by the use and protection of natural resources on and underneath the world's seabeds. Several chapters 
also carry a strong call for science-based decisions and the development of sound ecosystem-based management rules.

There have been numerous works on the law of sea with relevance for seabed uses and protection, in particular in relation to the deep seabed. ${ }^{1}$ However, there are to our knowledge few contributions which look at the seabed in such a comprehensive and transversal manner as the present book, covering several sectors, actors and jurisdiction areas.

This book aims to make several contributions to the literature. First, a common scientific knowledge basis is necessary to correctly design legal rules, appraise their consequences - known and potential -, and reach evidencebased decisions. ${ }^{2}$ Therefore, the book starts with a multidisciplinary definition of the seabed that is rarely provided. Second, the book presents an up-todate analysis of the most pressing and fundamental legal questions related to the use and protection of the seabed. It does this by juxtaposing sectoral regimes and comparing the regulatory approach in areas within and beyond the national jurisdiction. In doing so, the book argues for a more consistent and cross-sectoral approach, identifying some common management principles and tools. Third, many chapters offer a critical analysis and make suggestions for improvement of the applicable legal regime, the manner to fill legal gaps or to advance current treaty negotiations. In that sense, the book

1 See notably: K. Zou (ed.), Global Commons and the Law of the Sea, Maritime Cooperation in East Asia, Volume: 5 (Brill, 2018); A.G. Elferink and E.J. Molenaar (eds.), The International Legal Regime of Areas beyond National Jurisdiction: Current and Future Developments (Brill, 2010); J.M. Van Dyke, D. Zaelke and G. Hewison (eds.), Freedom for the Seas in the 21st Century - Ocean Governance and Environmental Harmony (Island Press, 1993); Rosemary Rayfuse, Research Handbook on International Marine Environmental Law (Edward Elgar Publishing Ltd, 2015); D. Vidas (ed.), Law, Technology and Science for Oceans in Globalisation (Brill, 2010); N. Bankes and S. Trevisanut, Energy from the Sea: An International Law Perspective on Ocean Energy (Brill, 2015); E. Egede, Africa and the Deep Seabed Regime: Politics and International Law of the Common Heritage of Mankind (Springer, 2011).

Some earlier publications are also of notable value, such as: Our Seabed Frontier: Challenges and Choices, National Research Council (The National Academies Press, Washington, 1989); The Ocean: Our Future, Independent World Commission on the Oceans (Cambridge University Press, 1998); M.G. Schmidt, Common Heritage or Common Burden?: The United States Position on the Development of a Regime for Deep Sea-Bed Mining in the Law of the Sea Convention (Oxford University Press, 1990).

2 As a matter of example, see the Treaty obligation for the European Union to take account of available scientific and technical data when preparing its policy on the environment (Art. 191.3, Treaty on the Functioning of the European Union). See, more generally, on evidencebased law making, but still in the case of EU law: Š. Majcen, 'Evidence based policy making in the European Union: the role of the scientific community' (2017) 24 Environmental Science and Pollution Research 7869. The European Commission refers itself to evidence-base decision making as part of its 'Better Regulation Agenda'. 
aims to contribute actively to several of the current processes at international, European or national levels.

Providing a new comprehensive and critical perspective on seabed regulation is also timely. The issues and concerns inherent to the seabed have been known for a long time, but new uses, new technologies, new knowledge about seabed ecosystems, higher tensions and potential disputes due to competing uses and interests, urge to reflect on which regulatory approaches to pursue.

In 2019, the United Nations (UN) celebrated the 25th anniversary of the entry into force of the 1982 United Nations Convention on the Law of the Sea (UNCLOS) ${ }^{3}$ and the establishment of the International Seabed Authority (ISA). ${ }^{4}$ The regime for deep seabed mining beyond national jurisdiction - in the Area -, which is under the competence of ISA, has developed towards a 'Mining Code', with the prospect of commercial activities getting increasingly realistic. So far, ISA has entered into 29 15-year contracts with contractors for the exploration of deep sea minerals, and the draft regulations on exploitation should be finalised in 2020 .

In parallel, UN negotiations have started on an international legally-binding instrument under UNCLOS on the conservation and sustainable use of marine biological diversity of areas beyond national jurisdiction. ${ }^{5}$ Marine genetic resources, including questions on the sharing of benefits, measures such as area-based management tools and marine protected areas, EIAs, and technology transfer are among the topics discussed.

Within national jurisdiction, states have been adopting legislation to implement UNCLOS and fulfil their obligations thereunder, but have also indicated looking at the exploitation of new minerals - beyond oil and gas - on their continental shelf, and have enacted new legislation in that sense. For example, in March 2019, Norway enacted a new Seabed Minerals Act, opening for exploration for and extraction of seabed minerals on its continental shelf. ${ }^{6}$ This new

3 United Nations Convention on the Law of the Sea (UNCLOS) adopted and opened for signature 10 December 1982, entered into force 16 November 1994, 1833 UNTS 3.

4 UNClos, Art. 156.

5 A Preparatory Committee was established by the United Nations General Assembly (UNGA) Resolution 69/292 of 19 June 2015 with the view of developing an international legally binding instrument under UNCLOS on the conservation and sustainable use of marine biological diversity of areas beyond national jurisdiction. In its resolution 72/249 of 24 December 2017, the UNGA decided to convene an Intergovernmental Conference to consider the recommendations of the Preparatory Committee. The first session of the Intergovernmental Conference took place on 4-17 September 2018 and the second session on 25 March-5 April 2019. The third session was convened from 19 to 30 August 2019. The fourth session is scheduled for the first half of 2020.

6 Lov om mineralvirksomhet på kontinentalsokkelen (havbunnsmineralloven) of 22.03.2019, entered into force on 1 July 2019. 
quest for minerals is fuelled by the needs of the digitalisation of the economy and the energy transition. It requires secure, stable and sufficient supply of metals and rare earth elements (REES) for electronic devices like smart-phones, or energy technologies like solar panels, wind turbines and electric vehicles. ${ }^{7}$

Since the laying of the first telegraph cable across the seafloor of the Atlantic between Britain and the United States in $1866,{ }^{8}$ continents have been increasingly interconnected. Interconnectivity is another feature of today's world which sets its mark on the seabed, whether it is for telecommunication purposes (cables for transfer of digital data including telephone and the Internet) or energy transport purposes between coastal states or for bringing energy to shore (oil and gas pipelines from production field, power cables from offshore wind farms, interconnectors). ${ }^{9}$ Those cables have developed to form a global network of undersea infrastructures which, in closed-basin seas such as the Mediterranean Sea, the Baltic Sea and the North Sea, results in a high number of crossings. Since each crossing is governed by a separate 'crossing agreement' entered into by the owners, the laying of a new cable or pipeline in the above mentioned sea areas usually involve the conclusion of a high number of those agreements. The laying of new undersea cables and pipelines may also involve crossing the continental shelf of other coastal states, a situation which may trigger the conclusion of a specific agreement between the states concerned, and/or the application of relevant provisions from UNCLOS ${ }^{10}$ and regional agreements. The two Nord Stream gas pipelines from Russia to Germany via the Baltic sea are good examples of such crossing situation, where delineation of the course for the laying, permitting procedures, due consideration to marine protected areas and national security interests have been among the legal issues at stake.

Those are only few examples of the new context for seabed resources management.

7 On the role of minerals and REEs in the digital economy and the energy transition, see for example: G. Pitron, La guerre des métaux rares : La face cachée de la transition énergétique et numérique (Broché, 2018); 'Substitution of critical raw materials in low-carbon technologies: lighting, wind turbines and electric vehicles', European Commission, Joint Research Centre, Öko-Institut e.V., 2016.

8 Other submarine telegraph cables had been laid down previously over more limited distances, like across the English Channel between France and Great Britain in 1852. Source: R. Salvador, G. Fouchard, Y. Rolland et A.P. Leclerc, Du morse à l'Internet, 150 ans de télécommunications par câbles sous-marins (AAcsM, 2006).

9 For a world map of submarine cables see for example $<$ https://www.submarinecablemap $. \operatorname{com} />$. 
2

\section{Access, Uses and Protection of Seabed Resources as Cross-Cutting Themes}

Three cross-cutting themes structure the book: access, uses and protection of seabed resources. A short introduction to those three themes follows below.

\subsection{The Legal Status of the Seabed and Access to Its Resources}

Once jurisdiction over seabed areas has been established through a process of delineation, coastal states can exercise their sovereign rights within their national jurisdiction. This results in a definition by the negative of the Area, which is 'the seabed and ocean floor and subsoil thereof, beyond the limits of national jurisdiction..11 It is notable that the question of delimitation of jurisdiction and of whom should have access to seabed resources, is relatively recent, and had mostly been a matter for private companies until the mid2oth century. ${ }^{12}$ Technological innovation has increased interest in the use of the seabed for purposes of control over resources and maritime spaces, and claiming jurisdiction has become the primary formal step for coastal states at the international level when the presence of seabed resources is proven.

Defining rules for delimitating the different maritime spaces according to a zonal approach, and defining the rights attached to those different zones, have been the primary focus of negotiators at the three UN Conferences on the law of the sea. Still today, defining the limits of national jurisdiction can be a contentious matter for coastal states aiming at harnessing seabed resources. ${ }^{13}$

Besides the tensions between coastal state's sovereign rights and maritime nations' interest in ensuring free access to oceans and straits, the voice of Arvid Pardo, the then Maltese ambassador to the United Nations, raised in 1967, calling for the adoption of a common status and regime for the seabed and the subsoil thereof' beyond national jurisdiction, which will secure 'the use of their resources in the interests of mankind'. ${ }^{14}$ The final text of UNCLOS defines the Area itself and its mineral resources as 'common heritage of mankind'. The status of common heritage of mankind involves the non-appropriation of the seabed by states or private entities, the sharing of benefits for the common

\footnotetext{
11 UNCLOS, Art. 1(1)(1).

12 See Chapter 3 of this book, H.W. Andersen, 'A short human history of the ocean floor'.

13 See notably the it Los Special Chamber, Judgment in Dispute Concerning Delimitation of the Maritime Boundary Between Ghana and Côte d'Ivoire in the Atlantic Ocean, 23 September 2017.

14 Arvid Pardo's speech, UNGA 22nd session, 1 November 1967, Agenda Item 92, full text available at <http://www.un.org/depts/los/convention_agreements/texts/pardo_garg67 .pdf>.
} 
good of humankind, and the use of the seabed for peaceful purposes only. ${ }^{15}$ The deep seabed and its resources is to be administered for the benefit of mankind as a whole, by ISA as an autonomous international organisation, on behalf of the international community.

This book discusses both the specific case of the Area and its mineral resources as well as spaces and resources falling outside that definition. For example, which legal status should be given to newly discovered resources such as marine genetic resources (MGR)? Do they pertain to global commons when located beyond national jurisdiction? Could the concept of common heritage of mankind apply to them? One recurrent theme in several chapters involves a discussion of the consequences of the legal status of the seabed on the types of exploitation and protection regimes we choose for seabed resources and ecosystems.

This can translate into a series of obligations for state and non-state parties. States in particular are bound by general principles defined in both treaties and international customary law, such as the precautionary principle or the prevention principle. More specific obligations can derive from the legal status of the seabed, such as in Article 194(2) UNCLOS which provides for due diligence in the respect of marine environment protection. ${ }^{16}$ This comes in addition to Article 192 UNCLOS which imposes on all States a general obligation to protect and preserve the marine environment. It can also translate into a more detailed legal regime for access and benefit sharing.

\subsection{Multiplication of Seabed Uses}

The oceans and the deep sea bed are increasingly coveted and are becoming ever more crowded. Innovations in marine technologies open for even more uses of the seabed than anticipated. There has been a multiplication and diversification of human uses of the seabed and its resources, and perspectives have differed between seeing the seabed as a medium (notably for the laying of infrastructures) and seeing it as a resource in and of itself (where seabed resources are both geological and biological). The spectrum of actual and potential uses has been constantly expanding and includes, notably, the laying of undersea cables and pipelines, marine research, extraction of petroleum and other mineral resources, exploitation of the renewable energy resources of

\footnotetext{
15 UNCLOS, Art. 137, 138 and 140(1).

16 See Advisory Opinion, Responsibilities and obligations of States with respect to activities in the Area, Seabed Disputes Chamber of the International Tribunal for the Law of the Sea, 1 February 2011, ITLOS Reports 2011, p. 10 (Case No. 17); UnCLOS Articles 208(3) and $209(2) 01$.
} 
the sea (wind, wave, tidal, storage), ancillary construction of islands and platforms (still mostly anchored), bottom fisheries, exploitation of marine genetic resources, military uses and even carbon dioxide storage beneath the seabed.

Tensions and legal issues are emerging out of the conflict of perspectives between those who define the seabed and its resources as the common heritage of mankind and those who seek to convert the ocean floor into a 'seabed factory.' ${ }^{17}$ The discussion of the conflicting interests between exploitation and conservation of the seabed and its resources is another leitmotiv in this book.

\subsection{Conflicting Uses, Coexistence, Resolving Mechanisms and Protection Regimes}

The multiplication of seabed uses leads to a discussion on their coexistence. The predominance of a sectoral approach is highlighted, and different solving mechanisms discussed.

Indeed, despite the overarching regime defined in UNCLOS, the regulation of ocean activities is essentially a sectoral matter, both within and beyond national jurisdiction. The same applies to the work of the different competent organisations, which often lacks close coordination and prevents further consistency between the regimes. ${ }^{18}$ Private parties are often relying on bilateral agreements to solve possible conflicts of uses of seabed space and resources. Finally, following a sectoral approach also means that gaps exist between the different regimes, bringing legal uncertainty and increasing the risk of fragmentation. The issue is known, but, as activities develop, there is a clear need for closer coordination at the overarching level, in the form of common principles, common tools and standardised practices.

While uses of the seabed are diversifying and the prospects of a 'blue economy' are expanding, 19 sustainable use and protection of the marine environment should act as an overarching goal, as reflected in UN Sustainable Development Goal 14 (SDG 14). SDG 14 aims to the conservation and

17 On the concept of 'seabed factory', see 'Getting to the bottom of it', Norwegian Continental Shelf 2-2016, pp. 14-17, available at <https://www.npd.no/globalassets/1-npd/publikas joner/norsk-sokkel-en/arcive/ncs-2-2016.pdf >.

18 See, as concerns ISA's works, Section XXII - 'Relationship with the United Nations and other relevant international organizations and bodies' in Report of the Secretary-General of the International Seabed Authority under article 166, paragraph 4, of the United Nations Convention on the Law of the Sea, ISBA/25/A/2, 3 May 2019, available at $<\mathrm{https} / / \mathrm{www}$.isa .org.jm/document/isba25a2>.

19 The sustainable exploitation of seabed resources is full part of the visions developed for the 'blue economy'. As a matter of example, see The EU Blue Economy Report 2019, European Commission, available at <http://periscope-network.eu/analyst/ annual-report-eu-blue-economy>. 
sustainable use of the oceans, seas and marine resources for sustainable development. ${ }^{20}$ This necessary common approach is justified by the essential place the seabed has in what can be called 'the oceans commons'.

\section{3}

\section{Content of the Book}

The book is divided into seven parts, following a systematic approach to the different issues of access, uses and protection of seabed resources, building on a distinction between the regimes applicable to areas beyond national jurisdiction and within national jurisdiction.

The book also balances theoretical chapters with case studies. Norway and the North Sea are at several occasions taken as examples due to the extent of seabed issues currently taking place in that region, but several chapters also present studies of the legislation in Australia, Canada, China, Namibia, New Zealand, Mexico, Papua New Guinea, Russia, South Africa and the United States of America (USA) in addition to the European Union and specific EU countries.

\subsection{Part I: Defining the Seabed}

Part I of the book offers a multidisciplinary definition of the seabed and its ecosystems. Indeed, it is necessary to combine knowledge of geoscience and marine biology to capture the richness and intrinsic characteristics of the seabed and its biodiversity. This science-based understanding of how the ocean floors have been formed, and what they contain and represent as ecosystems for species is put in perspective with a legal history analysis of its regulation over time.

Braathen and Brekke (Chapter 1), both geologists, provide readers with a fundamental understanding of the geoscience of the seabed. They describe the natural processes impacting the structure of the seabed, i.e. both its topography and subsurface geology. A detailed understanding of the seabed geology is a pre-condition to any exploitation decision and aims to ensure the good management of the resources, or, on the contrary, to preserve the seabed from any activity. The authors also address the manner how human activity impacts the physical seabed and could change it over time, affecting its physical consistency. They carry out an important message towards decision makers and the

20 For an update on the progress of SDG 14, see <https://sustainabledevelopment.un.org/ sdg14>. 
law community in general, making some recommendations as to the regulation of activities on the seabed.

Ramirez-Llodra (Chapter 2) describes the deep-sea ecosystems from a marine biology perspective. The chapter gives a unique picture of the high biodiversity and variety of faunal communities and their habitat which remain hardly accessible to most human beings. The deep seafloor has shown to support one of the highest biodiversities in the planet in a wide array of interconnected habitats. The chapter starts by presenting the general biological features and key ecosystem functions of the main deep-sea ecosystems. The chapter continues by describing the main human activities that affect, directly or indirectly, deep-sea habitats and their ecosystems. These anthropogenic impacts are grouped into 2 main categories: waste dumping and resource exploitation. As Braathen and Brekke did, this chapter asks for science-based decisions, with a call for a better understanding of deep-sea ecosystem composition, diversity and functioning, and the manner they response to stressors when considering resource utilisation regimes.

In his chapter (Chapter 3), Andersen gives us a short human history of the ocean floor. He reviews the long history of how western societies have perceived and to some extent experienced the deep ocean floor from the perils of the seafarers in the sixteenth century to UNCLOS III. The historical approach reveals how much influence the representation of the seafloor and its resources has had on their regulation. Importantly, Andersen makes clear the shift operated from conceiving the seafloor as a medium to looking at it as a resource. This shift in perception and interest also explains the shift in interest representation between private companies and national governments, between flag states and coastal states. The chapter ends by raising the question of the suitability of UNCLOS to answer the new challenges.

\section{2 \\ Part II: Delimitation of Jurisdiction over the Seabed and Right to Its Resources}

Part II of the book is dedicated to the principles applying to the delimitation of jurisdiction over the seabed as a necessary prerequisite to access to its resources.

Brekke (Chapter 4) reviews the main delineation principles currently applied in order to determine maritime jurisdiction of the coastal state over the seabed, as defined in Article 76 of the 1982 UNCLOS, and as interpreted by the courts. The chapter continues by reviewing the Norwegian experiences with setting the country's maritime boundaries, as a concrete application of the principles identified. The elements related to the organisation of the 
work for the purpose of submissions to the Commission on the Limits of the Continental Shelf (CLCS), the mapping of the outer limits and to the cooperation with neighbouring states are successively analysed. The chapter ends with an overview of the currently identified resources on the Norwegian continental shelf.

Skaridov (Chapter 5) explores the question of delimitation of jurisdiction in the Arctic as a fundamental starting point for discussing the regime of exploration for and exploitation of seabed resources in an area of the world which is subject to competing state and commercial interests, and so a source of potential conflicts. The author starts by pointing out the difficulty of establishing a precise scientific knowledge basis as to the volumes of resources contained in the Arctic seabed. Most part of the chapter is then dedicated to the question of competing claims and the analysis of Arctic states agreements and disputes regarding the establishment of baselines, the delimitation of the state territories and the applications in the view of establishing the outer limits of continental shelf submitted to the CLCS. The chapter also reviews the national Arctic strategy of the five Arctic coastal states. The author advances several proposals on possible ways of resolving disputes.

Brazovskaya and Ruchkina (Chapter 6) offer a study of the international regulation of the seabed in the Antarctic, and address the two topics of delineation of maritime spaces and use of seabed mineral resources. In the absence of a conventional delimitation of Antarctic spaces, the authors start by addressing the challenging task of establishing the boundaries in the polar regions, which are constantly covered with ice and, accordingly, the difficulty of measuring the width of the territorial sea and the EEz. Second, the authors note that despite the fact that this continent was discovered already in 1819, its geographical and climatic features do not allow its full use. Meanwhile, a series of legal principles defined in the Antarctic Treaty System put limits on the use of the territory, limiting it to peaceful purposes and scientific research. In that context, the authors discuss the international legal regime which would apply to the exploration for and exploitation of Antarctic mineral resources, since, as they state, sooner or later, the question of industrial extraction of Antarctic natural resources will be raised. Given the 'frozen' territorial claims of countries, the authors argue that this will require the adoption of a special legal regime for the continental Antarctic shelf as an alternative to the continental shelf regime in the sense of the 1982 UNCLOS.

\section{$3 \cdot 3$}

Part III and IV: Exploitation of Non-Living, Living and Marine Biodiversity Resources in Areas beyond National Jurisdiction

The next two parts of the book look at the areas beyond national jurisdiction $(\mathrm{ABNJ})$, first for the exploitation of non-living resources (Part III) and then for 
the living and marine biodiversity resources (Part IV). Putting the regime for living and non-living resources in parallel enables to draw conclusions in terms of suitability of a common approach, or, on the contrary, the need to design different models, notably for the purpose of benefit sharing.

Part III of the book dedicated to non-living resources starts with Dingwall's chapter (Chapter 7), which provides a comprehensive analysis of the international legal framework applicable to deep seabed mining beyond national jurisdiction, i.e. in the Area. This framework was elaborated under UNCLOS, leading to the establishment of ISA. ISA governs deep seabed mining activities on behalf of humanity, as a reflection of the qualification of the deep seabed as 'common heritage of mankind'. The Authority is responsible for regulating the Area and granting mining contracts to allow States and other entities to explore for and exploit deep seabed minerals. The Chapter reviews the key elements of this regime, the current level of activity and the role of the different actors - ISA, contractors, state sponsors, the Enterprise -, and discusses as well the case of actors still outside the UNCLOS deep seabed mining regime (nonStates Parties to UNCLOS, such as the USA).

Røsæg (Chapter 8) continues the discussion on deep seabed mining by identifying gaps in the currently applicable regime that prevent moving forward towards commercial activities in the Area. The unclear applicable regime for mortgaging the equipment involved in mining operations is seen as a problem. Other examples involve patent infringements, labour protection, and extra contractual liabilities. Balancing the pros and cons of acting outside or within the scope of the Authority, the chapter discusses different possible alternatives, and which role sponsoring states and flag states could play for filling the legislative gaps and offering a more sound framework legislation for commercial activities in the Area than just adding conditions to licenses.

Activities in the deep seabed area beyond national jurisdiction raise important maritime security issues such as the emplacement of weapons of mass destruction, prospects of piracy and terrorism against ships engaged in deep seabed mining activities, as well as the challenge that deep seabed mining could actually raise as regards environmental security. Yet, relatively little has been written on maritime security and the Area. Egede makes therefore an important contribution (Chapter 9) by investigating possible maritime security issues that could arise in the Area. In doing so, the chapter takes both a rather traditional state-centric maritime security approach and a more nonState centric viewpoint. When discussing the notion of maritime security in the law of the sea, Egede points out the increasing shift from a sole focus on States actors to an increasing engagement with diverse non-State actors. Non-state actors which include international organizations, private maritime security companies, pirates and armed robbers at sea, private fishing trawlers 
engaged in Illegal, Unreported and Unregulated (IUU) fishing, terrorists groups and victims of maritime crimes. This shift is accompanied by new interactions between State actors and non-State actors involved in peaceful and lesspeaceful activities. This triggers a discussion of the applicable international legal framework, including the one under the responsible of ISA.

Part IV of the book is dedicated to the exploitation of genetic resources and living resources, a topic which has concentrated much attention lately, with the ongoing negotiations on the use of marine biological diversity in areas beyond national jurisdiction (BBNJ). ${ }^{21}$ All three authors come with critical analysis of the current regime, the existing gaps and make suggestions for improvement.

Scovazzi (Chapter 10) discusses rights to genetic resources in ABNJ, which is one of the central issues of the ongoing negotiations at the United Nations. Among the still pending questions are whether the new regime will be based on freedom of the sea or common heritage of mankind or a third sui generis approach. Other notable questions relate to access to the resources, benefitsharing (both non-monetary and monetary benefits), inclusion of genetic resources of the water column, intellectual property rights, role of traditional knowledge, and 'straddling' genetic resources.

Tvedt (Chapter 11) continues the discussion started by Scovazzi, looking at the potential elements in regulating rights and use of genetic resources in $\mathrm{ABNJ}$, as it appears that the existing Access and Benefit Sharing (ABS) regimes cannot just be copy-pasted. The author follows a practical approach and explores different models for how to make an ABS-system for ABNJ legally binding on users. This means that all suggestions are tested against whether it would be possible to oblige private parties to a system of both access and benefit sharing. For example, the chapter provides a clear view on how the proposed regulatory model can be aligned with the exclusive rights awarded by patents when the activity results in an invention. The chapter discusses open and semi-open source options for using repositories as a practical means of securing access to the resources for the many. It highlights the potential role of private contracts for such a global regime to become functional.

Caddell (Chapter 12) looks at the regime for exploitation of living resources directly on the seabed in the ABNJ. While limited regulation existed in relation to bottom fisheries two decades ago, the UN General Assembly has played an essential role, calling for the protection of vulnerable marine ecosystems (VMEs) on the seabed in a series of highly influential Resolutions. This political impetus has prompted the adoption of complementary conservation and management measures by regional fisheries management organisations

21 See above $\left(\mathrm{n}_{5}\right)$. 
(RFMOs), flag states and other actors. The chapter reviews the progress made in the development of standards for deep-sea bottom fishing. It also identifies a series of shortcomings in the implementation of those standards, and advances a series of recommendations as to the future of the regulatory regime.

\subsection{Part v: Principles Applicable to Sovereign States When Exploiting Seabed Resources within National Jurisdiction}

Part $\mathrm{v}$ of the book looks at the manner sovereign states regulate or intend to regulate the exploration for and exploitation of seabed resources within their national jurisdiction, and which constraints international and European law put on the development of national legislation.

Roux and Horsfield (Chapter 13) offer a series of case studies of national legislations applicable to seabed mining within the national jurisdiction of coastal states. Interest in exploration and exploitation activities has been increasing over the past decade and has largely been concentrated in the EEZ of five states namely: New Zealand, Australia, Namibia, Mexico and Papua New Guinea. The approach, policy positions or decisions adopted by these countries in relation to seabed mining within their jurisdictions has generally been cautious, with due regard to the precautionary principle. These have ranged from permanent bans, moratoria, strategic environmental assessments and reviews by environmental agencies. Through a comparative analysis of these cases, the chapter identifies a structure for decision-making on seabed mining that can be used by coastal States.

Arnesen, Greaves and Pozdnakova (Chapter 14) look at the example of the European Union, and how the latter intends to regulate Member States' activities on the seabed. The authors consider the question of EU competences with respect to the seabed, namely whether the EU has competence; what kind of competence it has (shared or exclusive), and the territorial limits of this competence (functional approach). Then, the authors examine how the EU deals with two specific sectors in light of new challenges, namely, seabed mining and environmental protection and liability.

Chen (Chapter 15) offers another case study, reviewing the 2016 Law of the People's Republic of China on Exploration for and Exploitation of Resources in the Deep Seabed Area (the Deep Seabed Law). The enactment of the law and its implementing regulations represents China's national implementation of UNCLOS. The chapter raises two central questions: why does China need this law and why 2016 represented a positive context for its adoption. The author undergoes a systematic review of the provisions of the Deep Seabed Law, commenting specifically the three core intents, namely controlling, securing and 
preparing. The author also compares the Law with the equivalent legislation of other countries and concludes with an assessment of the limitations and impact on China's other areas of law. This chapter provides readers with a better understanding of China's strategy of building a 'deep sea maritime power' by 2020. By pointing out the legal innovation of the Deep Seabed Law, the author argues that it could serve as a reference for other countries that intend to incorporate UNCLOS obligations on deep seabed mining into their domestic legal system.

Chircop (Chapter 16) examines Article 82 of UnCLOs, which is a novel provision introducing the first-ever international royalty on production from non-living resources within national jurisdiction, specifically from the extended continental shelf as defined in Article 76 . The author points out that Article 82 has several textual ambiguities that could pose a challenge for its interpretation and implementation by both affected coastal States and ISA. The Authority plays a particular role in the implementation of Article 82 , since it is responsible for receiving payments or contributions in kind and for effecting their distribution to States Parties to the Convention, especially developing countries, in accordance with equitable criteria. Article 82 is expected to be first activated on Canada's extended continental shelf off Newfoundland in the Northwest Atlantic. In implementing Article 82 Canada faces domestic political, economic and legal challenges, in addition to the textual ambiguities. This chapter discusses the major issues and underscores the important leadership and precedential role played by Canada in domesticating Article 82 and developing a relationship with the Authority on this matter.

\subsection{Part VI: Building, Operating and Removing Installations on and beneath the Seabed}

Part VI of the book looks at the applicable regimes for the building, operating, re-moving and even re-use of installations on and beneath the seabed. The use and re-use of installations in connection to storage of carbon dioxide $\left(\mathrm{CO}_{2}\right)$ under the seabed is also part of the upcoming topics which need further legal scrutiny.

Bankes (Chapter 17) examines the legal issues associated with the use of sub-seabed transboundary geological structures, including saline aquifers, for storage or disposal purposes focusing on the geological sequestration of $\mathrm{CO}_{2}$. Underground $\mathrm{CO}_{2}$ storage represents the final stage of the carbon capture and storage (CCS) chain. The chapter reviews the existing law requirements and guidelines that frame the operations of injection of $\mathrm{CO}_{2}$ as part of enhanced oil recovery (EOR) as well as $\mathrm{CO}_{2}$ disposal or storage operations $\left(\mathrm{CO}_{2} / \mathrm{EOR}\right)$, 
such as the Protocol to the London Dumping Convention. It also discusses the implications of Articles 74(3) and 83(3) of UNCLOS for the situations of transboundary geological storage sites, including in areas of overlapping maritime entitlements. The author examines how these issues have been or could be dealt with in delimitation agreements, framework agreements and joint development agreements. As the $\mathrm{CO}_{2}$ storage projects worldwide get closer to operating phase, the legal issues raised by Bankes become increasingly imperative to consider.

Trevisanut (Chapter 18) addresses the issue of decommissioning of installations placed on the seabed. The number of offshore installations, reaching the end of their life-cycle, are increasing and many of them can represent an environmental hazard or area threat for other legitimate uses of the sea and the seabed. This time constraint put on decommissioning decisions calls for an analysis of the applicable international legal framework, as undergone by the author who also highlights some of its ambiguities. The chapter offers a systematic review of the legal regime incorporated into UNCLOS, and continues by focusing on generally accepted international rules and standards (GAIRS) at both a global and regional level. The author makes important conclusions as to the manner the lack of a binding instrument at the universal level, and the geographical fragmentation of the existing legal regime act as an obstacle to the development of clear global GAIRs, and thus to a more coherent and effective legal framework for the decommissioning of offshore installations.

Roggenkamp's chapter (Chapter 19) makes the link between the two topics of decommissioning of offshore installations and $\mathrm{CO}_{2}$ storage and disposal. The author examines the possibility of using depleted oil and gas fields in the North Sea area for $\mathrm{CO}_{2}$ storage. An important issue in this regard is the relationship with the removal obligations that exist offshore. Instead of removing the installations after the oil/gas production has ceased, the possibility to re-use the depleted reservoir for $\mathrm{CO}_{2}$ storage could entail that the offshore installations and pipelines have to be kept in place. The chapter looks into this possibility from the perspective of both international law and the national law of three North Sea coastal States: the Netherlands, United Kingdom and Norway. This review reveals legal uncertainties for the transitional period between production ceases and a $\mathrm{CO}_{2}$ storage permit is awarded. As the exploitation of oil and gas fields in the North Sea area is ageing and maturing, and although first steps have been made to facilitate re-use of installations, the author calls for legislators and policy makers to act and seize this window of opportunity.

In his chapter (Chapter 20), Harrison explores the extent to which the investment treaty framework can be applied to seabed investments and, if 
so, the scope of protection that may be expected by investors. It addresses the geographical scope of international investment treaties, and considers the substantive protections that are available if a seabed investment is found to fall within the scope of those treaties. It also questions whether the treaties can be applied to seabed investments made within the jurisdiction of coastal states. The analysis demands an understanding of how international investment law interacts with relevant rules in the international law of the sea and international environmental law. Given the intensification in seabed activity around the world, there is a need to clarify key issues that arise in the interpretation and application of investment standards in this context.

Waverijn (Chapter 21) questions to which extent seabed installations can be mortgaged as a way of reducing financing risks. To conduct his analysis, he takes energy installations in the North Sea as study case. Indeed, offshore oil and gas, offshore wind and ocean energy projects are capital intensive with billions of euros required for their construction. It is common business practice to raise debt to finance them, which is more expensive when risks are greater. Security rights such as mortgage and pledge reduce the risks of lenders, however restrictions exist under national law. In his chapter, the author analyses the solutions provided under Dutch property law, as it is currently impossible to mortgage installations situated on the seabed further than 22.2 kilometres off the Dutch coast. In his view, allowing for such mortgages could benefit the development of the offshore energy sector as this would reduce risks.

\subsection{Part VII: Conflicting Uses or Coexistence, Resolving Mechanisms and Protection Regimes: Towards a More Integrated Approach}

The final part of the book, Part VII, is dedicated to the question of coexistence between activities competing for the same seafloor area and which regime exists for solving conflicts in uses, such as resolving mechanisms. It contains a call for more consistency in the approach of coexistence of activities, but also in the manner divergent interests, including environmental protection and sustainable use of the oceans, can be conciliated through management tools.

Rayfuse (Chapter 22) examines the general principles which lay the basis of normative frameworks and management approaches in the efforts to promote cross-sectoral cooperation and coordination, and avoid inter-sectoral conflicts and negative decisions for the conservation and protection of the marine environment. Her chapter reviews the new cross-sectoral management approaches and tools that are emerging. It then turns to a discussion of the key tools that have been developed to assist environmental management of marine and seabed uses and an examination of emerging frameworks for cross-sectoral management aimed specifically at avoiding, minimising or resolving conflicting uses on the seabed, particularly in ABNJ. 
Askheim's chapter (Chapter 23) deals with agreements between owners/ operators of crossing pipelines, power cables and telecom cables (all termed connectors) on the seabed. It reviews the legal basis for such agreements as well as their main provisions. The manner in which liability and indemnity clauses are designed is given attention throughout the entire implementation of the project (pre-completion, construction and post-completion). The chapter makes clear the need to complete the provisions of UNCLOS in specific crossing agreements as a way by which the owners of subsea transportation assets can organise themselves in the most balanced and predictable manner.

Using the Nord Stream gas pipelines in the Baltic Sea as a case study, Langlet (Chapter 24) investigates how competing interests relating to submarine pipelines are handled by the law of the sea. Particular attention is given to the role of transit states - i.e. States over whose continental shelf a pipeline is laid without it entering their territorial waters - and the limits to their right to regulate the laying of pipelines and thus act as arbiters of potentially competing interests such as the right of transport, the effective protection of the marine environment, and national security considerations. Only some few interests are recognized by UNCLOS as legitimate bases for a coastal State to adopt measures, but it could be tempting to use such grounds to pursue other objectives. It is concluded that although the pertinent rules in UNCLOS are complex and partly vague, the States concerned have in most cases diligently avoided pushing the limits of coastal State jurisdiction as set out in the Convention.

Svendsen (Chapter 25) looks at the regime for liability and compensation, and discusses which manner can best compensate damage caused by deep seabed mining activities in the Area. The author takes the view that the draft regulations for exploitation, in their present form, do not construct an adequate model for liability and compensation for damage as a result of these activities. The chapter sketches the current parallel system of the sponsoring State's responsibility for damage caused in the Area and the sponsored contractor's liability for damage caused in the Area. The chapter attempts to draw a model for an improved liability and compensation system for damage caused by deep-sea mining in ABNJ.

\section{Acknowledgments}

This book is the result of international collaboration between researchers gathered under the Oslo Law of the Sea Forum, 'OsLos', a research 
network of the Scandinavian Institute of Maritime Law at the University of Oslo. ${ }^{22}$ The success of the project is a tribute to all the authors, each of whom has contributed greatly in delivering state-of-the-art research in his or her specialized area of research.

The gathering of authors at the preparatory meeting in Oslo was made possible by funding received from the MARINFORSK programme of the Research Council of Norway (project number 255761).

The present editor would also like to thank Prof. Erik Røsæg and Prof. Henrik Ringbom for the opportunity to lead this project.

Finally, this book would not have been realized without the continual support of the publisher. Special thanks go to BRILL and their team for steadfast confidence in the project and vital support throughout the entire process.

22 Website of the Oslo Law of the Sea Forum (osLOs): <https://www.jus.uio.no/nifs/english/ research/projects/oslos/index.html>. 